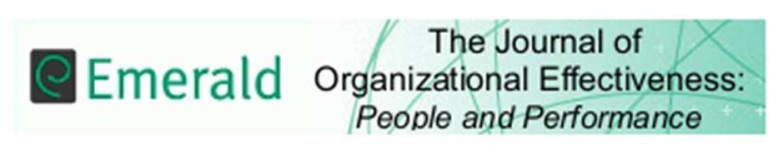

\title{
The Changing Contours of Fairness: Using Multiple Lenses to Focus the HRM Research Agenda
}

\begin{tabular}{|r|l|}
\hline Journal: & Journal of Organizational Effectiveness: People and Performance \\
\hline Manuscript ID & JOEPP-01-2016-0004 \\
\hline Manuscript Type: & Research Paper \\
\hline Keywords: & Fairness, Organizational justice, Social Structures, Intergenerational Equity \\
\hline \multicolumn{2}{|c}{} \\
\hline
\end{tabular}

\section{SCHOLARONE ${ }^{\text {Ix }}$ \\ Manuscripts}


Structured Abstract

\section{Purpose}

Organizational justice research has become the main paradigm of research in the field of HRM. The paper outlines a number of underlying challenges to which this paradigm is illsuited. It broadens the traditional understanding of what is meant by fairness within the HRM literature to help explain how justice judgements are formed and may be used to influence societal level fairness processes. It develops a framework to aid our understanding of the fairness of decisions that individuals or organizations make.

\section{Design/methodology/approach}

The paper presents a conceptual review of the main paradigms used in fairness research. It draws upon the organizational justice literature as the dominant paradigm in HRM research, and conducts a cross-disciplinary review that introduces a range of theories less frequently used by HRM researchers - specifically capability theory, game theory, tournament theory, equity sensitivity theory, theories of intergenerational equity and burden sharing. It demonstrates the relevance of these theories to a number of areas of organizational effectiveness.

\section{Findings}

The paper shows that researchers are now augmenting the organizational justice research paradigm under two important pressures - (1) awareness of hidden structures that preclude the option for real fairness; and (2) new variables that are being added to the consideration of organizational justice.

\section{Research limitations/implications}

The fairness theories are used to identify a number of important and future research agendas in the field of HRM. Many of the judgements made by employee suggested by the theories now need measurement at the individual level. It remains to be seen whether these 
judgements are highly situational and context-dependent or may be used to identify important individual characteristics. It is also likely that fairness judgements act as an important of a range of HRM-related outcomes such as trust and engagement.

\section{Practical implications}

HR functions have invested significant resources in employee engagement or insight units, but if their policies trigger significant inequality of outcomes, perceived problems of justice, a lack of burden sharing, no sense proportionality, organizations may not be able to achieve other important HR strategies such as sustaining and deepening employee engagement, developing organizational advocacy, building an employer brand, or being seen to have authenticity in its values. The framework suggests a broadened educational base for HR practitioners around fairness. It also suggests that there may be complex employees segments concerning perceptions of fairness.

\section{Originality/value}

The cross-disciplinary perspective taken on fairness helps deconstruct the judgements that employees likely make, enabling organizations and individuals alike to ask more critical questions about their respective behaviour.

\section{Keywords:}

Fairness, Justice, Inter-generational, Hidden social structures, HRM

\section{Paper type}

Research paper 
The Changing Contours of Fairness: Using Multiple Lenses to Focus the HRM research agenda

\section{Introduction}

A number of developments have made it timely to review concepts of fairness and the implications for research in HRM. We are living through a period where substantial transfers of costs, risk, responsibility and accountability are taking place, and these transfers are between markets, nation states and supra-national bodies, organizations and individuals - and indeed at the individual level also amongst different generations. As we consider the future of work and expectations of the employment relationship, therefore, complex questions of what is fair or unfair are being generated. The actions of organizations are invoking deep questions about what is fair or not: pension provision, questions about the adequacy or excessiveness of rewards, use of zero-hours contracts, the quality of careers across age groups, levels of social mobility, and the global sourcing of work. In terms of agency, organizations are operating in an environment where what is happening outside them may become as significant a shaper of employee behaviour as what they do within the organization.

Fairness refers to the idea that an action or decision is morally right (Tabibnia, Satpute, \& Lieberman, 2008). The theoretical literature on fairness makes it clear that in any situation there are many allocations that could be considered as fair. However, which of these perceptions of fairness are actually held by people in practice? The general conclusion from the existing empirical literature is that there is no one dominant fairness concept, principally because fairness concepts differ with the context of the situation and with the individual (Otaye \& Wong, 2014). 
Given the difficulty in establishing the fairness concept, organizational scientists have resorted to explaining the concept by providing a thorough description of the facets of justice as an experience (Greenberg, 1987a, 1987b, 1987c, 1990; Crawshaw, Cropanzano, Bell \& Nadisic, 2013). This has become the main paradigm of research in the field of HRM. By paradigm we mean a framework or theme that is underwritten by a set of theories, methodologies, ways of thinking, or model. Organizational justice concerns the moral rightness of a decision or treatment (which may be defined according to ethics, religion, fairness, equity, or law) as perceived by individuals, in their appraisal of the fairness of a situation. Specifically, organizational justice research suggests that individuals evaluate at least three aspects of their work environment - (1) distributive justice - the fairness of one's outcomes from a decision-making system (Adams, 1965; Leventhal, 1976); (2) procedural justice - the fairness of the processes used to decide those outcomes (Thibaut \& Walker, 1975; Leventhal, 1980); and (3) interactional justice - the fairness of the interpersonal exchanges that occur during work (Bies \& Moag, 1986; Greenberg, 1993). More importantly, beyond these issues of description and structure, organizational justice research has tended to focus on four interrelated theoretical questions: (1) why justice at work matters to individuals; (2) what factors are antecedent to justice; (3) what are the consequences of justice and injustice; and (4) how justice judgements are formed (e.g. Cropanzano et al., 2001; Greenberg, 2001; Ambrose, 2002; Blader \& Tyler, 2003; Crawshaw et al., 2013). Questions one to three have received ample attention over the years (e.g. Tyler \& Bies, 1990; Cropanzano et al., 2001; Cohen-Charash \& Spector, 2001; Colquitt et al., 2001; DeCremer, 2005; Crawshaw et al., 2012).

Following the seminal work of Greenberg (1987a, b, c, 1990) and existing scholarly reviews by. Colquitt, Colon, Wesson, Porter and $\mathrm{Ng}$ (2001) on organizational justice, a substantial literature has now evolved regarding the influential role justice plays on individual 
attitudes and behaviours. Whilst research into organizational justice has many implications for the HRM domain, particularly, in our understanding of fairness as a psychological process, in judging fairness, there are a number of underlying challenges that it is ill-suited to explain. To complement this literature, in this paper we aim to explain a range of individual and organizational level fairness theories that influence societal level processes and aid the justice or fairness decisions that individuals or organizations make. The paper attempts to provide a more integrated, complete, and accurate model of the psychological determinants that underlie justice formations.

In order for academic research to address these issues, we believe that we need to broaden the traditional understanding of what is meant by fairness that is applied within the HRM literature. We argue that existing research on fairness from an organizational justice perspective leaves us with two research problems. First, we need to be able to better deconstruct how employees frame their judgments of fairness if we are to understand the cognitive and emotional processes through which fairness judgements are formulated, and that underlie its effects. The paper introduces a range of theories that have featured little in HRM research but that have surfaced hidden structures that may preclude the option for fairness. Second, and broadly as a consequence of the first problem, we need now to introduce some new variables and perspectives to our considerations of organizational justice. The conceptual model that we follow is summarised in Figure 1.

\section{$<$ FIGURE 1 AROUND HERE >}

The aim of this paper is to deliver a credible framework for research into fairness intended to facilitate a more mature employment relationship with a richer, constructive 
conversation between organizations and their employees, managers and their reports around aspects of fairness. We start by providing a detailed review of the dominant paradigm in Human Resource research on fairness - that of organizational justice. Particular attention is given to distributive, procedural and interactional justice. We then draw on cross-disciplinary work on fairness in order to make two arguments. First, when making fairness judgements, there are hidden structures that preclude the options for real fairness. These hidden structures aid the cognitive frameworks individuals use in making judgements. We draw on capability theory, game theory and tournament theory in developing this argument. Second, recent economic and global changes are creating new dimensions which need to be added to the consideration of organizational justice. We draw on inter-generations equity theory and equity sensitivity theory in developing our argument. Finally, we review the implications for HRM of a range of different literatures on fairness and maps the contours of fairness in a way that is useful to HRM researchers.

\section{Organizational Justice}

The dominant paradigm within the HRM literature on fairness has been organizational justice, which comprises of distributive justice, interactional justice, and procedural justice (see; Cropanzano \& Greenberg, 1997; Cohen-Charash \& Spector, 2001; Colquitt et al., 2001 and Greenberg \& Colquitt, 2005 for literature reviews). We explain the principles that dominate this paradigm. According to Rupp, Shao, Jones \& Liao, (2014) these three constructs are assumed to represent employees' perceptions of whether the outcomes they receive, the procedures used to determine outcomes, and both the information conveyed about procedures and the interpersonal treatment bestowed as information is shared, are all fair. 
Distributive justice is broadly defined as the fair distribution of resources (Greenberg \& Colquitt 2005). Within the organizational and HR literature, it has been shown to be negatively related to turnover intention (e.g.,Griffeth et al., 2000; Poon, 2012), positively related to affective commitment (Poon, 2012) and to be associated with affective (e.g., resentment), cognitive (e.g., perceptual distortion), and behavioral (e.g., withdrawal) reactions to particular outcomes (Cohen-Charash \& Spector, 2001). This form of justice is most commonly discussed in relation to equity theory (Adams, 1965). According to Adams' equity theory, people determine fairness via a deliberate and reasoned calculation and evaluation of their perceived contributions or inputs (i.e. skills, effort, performance) relative to the outcomes (tangible and intangible rewards) they have received. They then compare this ratio to some comparison or referent standard to determine whether the outcomes they have received for their efforts are fair (Nowakowski \& Conlon, 2005). Injustice is thus perceived when these input-outcome ratios are felt to be positively or negatively imbalanced. A situation or event will be interpreted as unfair when three judgements are made by individuals, termed 'would', 'could', and 'should' judgements (Folger and Cropanzano, 1998, 2001). A number of related theories, notably the 'fairness heuristic theory' developed by Lind $(1995,2001)$ and the 'uncertainty management theory' (Van den Bos and Lind, 2002), argue that these judgements about fairness and equity need not be deliberate but are also made relatively automatically and intuitively. Therefore, according to this paradigm, people make equity assessments by comparing their outcomes (rewards, such as pay raises) and inputs (their contributions, such as effort exerted) to the outcomes and inputs of others (Poon, 2012). Distributions are fair to the extent that employees perceive their rewards to be proportionally matched to their contributions (Ambrose \& Arnaud, 2005).

According to justice theory, there are three common "allocation norms" (Colquitt et al., 2005) that are invoked when judging the fairness of how some good is distributed. These 
norms are usually termed equity, equality, and need (Deutsch, 1975). Equity-based justice is rooted in the sense of proportion (Adams, 1965) - the sense that the outcomes individuals receive (remuneration, a corner office, or any other valued outcome) should be awarded in proportion to their inputs (how hard they work, how productive they are) (Morand \& Merriman, 2012). In general, the equity norm is used to foster high levels of task performance (Leventhal, 1976). By reinforcing beneficial inputs, the decision maker is expecting individuals to contribute increasing amounts of such inputs to the organization. The equality rule argues that people should be rewarded equally (Young, 1995) and all participants receive the same outcomes, regardless of their individual performance levels. This norm is used to minimize dissatisfaction and reduce incidence of disruptive, antagonistic behavior on the part of those who might be dissatisfied under an equity allocation rule (Leventhal, 1976). Finally, the need rule argues that people should be rewarded based on their level of need or deprivation (Nowakowski \& Conlon, 2005). Equity, equality and need may all be applied in different situations in organizations. For example, salary adjustments are typically made on past performance (equity). However, travel and support budgets may be allocated identically (equality). Choice of office space in a new building may be determined by rank in the organization (another form of equity). Newly hired faculty may receive a large support budget and summer stipend (need). However, there is little consensus regarding when each type of rule is most likely to be used or when each rule is likely to be seen as most fair. Nowakowski and Conlon (2005).

Procedural Justice is referred to as the fairness of process used to arrive at decisions (Konovsky, 2000). Within the HRM domain, research has shown positive relationships between HRM practices and procedural justice. For example, Meyer and Smith (2000) found a positive link between promotion, career development and training opportunities, satisfaction with the employee benefits packages, performance appraisal, and perception of 
procedural justice. Similarly, Paré and Tremblay (2007), in a study of information systems specialists, found that perception of procedural justice was significantly associated with fair rewards practices, skills development, non-monetary rewards and information sharing. Finally, Tremblay, Cloutier, Simard, Chenevert \& Vandenberghe (2010), in their research showed that non-monetary reward practices and bottom-up information practices act positively on procedural justice.

It is worth remembering that although this concept is now more commonly used across the organizational effectiveness literature, it originated within the context of legal procedures. Researchers studying law and psychology noted that participants in dispute resolution procedures did not merely react to the outcomes that they received, but also to the process by which they receive those outcomes (Nowakowski \& Conlon, 2005). Thibaut and Walker (1975) originally developed this construct, describing the disputant reaction to different types of legal procedures in terms of their reactions to both the process used and the outcome received and the amount of influence disputants had in each stage as evidence of process control and decision control. Disputants were willing to give up control in the decision stage as long as they retained control in the process stage. Stated differently, disputants viewed the procedure as fair if they perceived that they had process control (i.e., control over the presentation of their arguments and sufficient time to present their case) (Colquit, Colon, Wessen, Porter \& Ng, 2001). This process control effect is often referred to as the "fair process effect" or "voice" effect (e.g., Folger, 1977; Lind \& Tyler, 1988). Although Thibaut and Walker (1975) introduced the concept of procedural justice, their work focused primarily on disputant reactions to legal procedures. Other researchers have since then elaborated on Thibaut and Walker's work by suggesting other characteristics of procedural justice. 
Leventhal and colleagues can be credited for extending the notion of procedural justice into non-legal contexts such as organizational settings (Leventhal, 1980; Leventhal et al., 1980). In doing so, Leventhal and colleagues also broadened the list of determinants of procedural justice far beyond the concept of process control. They suggested a multidimensional approach to procedural justice and argued that procedures were fair to the extent that they met six criteria: procedures need to be (1) accurate; (2) consistent, both temporally and interpersonally; (3) ethical; (4) correctable; (5) able to insure bias suppression; and (6) able to ensure representation. Hence, according to Leventhal's (1980) theory of procedural justice, a fair procedure is one that is applied consistently, is free from bias, is based on accurate information, has some mechanism for correcting wrong decisions, conforms to ethical standards, and gives those affected voice (Colquitt et al., 2001). Fair procedures are valued because they (a) give people some control over decisions and are thus regarded as instrumental for achieving fair outcomes; and (b) communicate to people their standing in a group, with fair procedures signalling that they are respected in the group (Blader \& Tyler, 2005). Often the term 'procedural justice', connotes structural features of the decision-making process, such as the amount of employee voice (Nathan, Mohrman, \& Milliman, 1991; Folger \& Lewis, 1993), the appropriateness of evaluative criteria (Greenberg, 1986, 1987a; Nathan et al., 1991), and the accuracy of the information used to render a decision (Greenberg, 1987b).

The third and final element of justice has been called Interactional Justice. This involves the human or social aspect of organizational practices (Chou, 2009). It focuses on the quality of interpersonal treatment (Cropanzano, Prehar \& Chen, 2002; Landy \& Conte, 2004) and examines how people in charge of allocating resources and rewards in the workplace behave toward the recipients (Kernan \& Hanges, 2002). Research has shown that interactional justice is positively related to OCB (e.g. Masterson et al., 2000) and other forms 
of employee behavior and attitudes. Bies and Moag (1986) introduced this concept in the justice literature by focusing attention on the importance of the quality of the interpersonal treatment people receive when procedures are implemented. When making decisions about interactional justice, employees judge whether their supervisor has treated them with dignity and respect, refrained from making inappropriate remarks, or given them adequate justification for a recent decision (Bies and Moag 1986). It is fostered when people are treated with respect and sensitivity, and the rationale for decisions is explained to them thoroughly (Colquitt, 2001). On this basis, some scholars have conceptualized interactional justice as comprising two dimensions: interpersonal (capturing the personal treatment part) and informational (capturing the explanation part) (Greenberg, 1993; Colquitt et al., 2001). Interpersonal justice relates to how employees are treated during the enactment of procedures (e.g., concern for one's plight; being treated with honesty, respect, and dignity). Informational justice refers to the accuracy and quality of explanations about procedures provided to employees (Colquitt et al., 2001).

\section{Limitations to the organizational justice paradigm}

The organizational justice paradigm has had a proud history in the field of HRM and this paradigm has served researchers in the field of HRM well. Overall, research into organizational justice shows that perception of organizational justice has a positive relationship with many desirable work and organizational effectiveness outcomes such as organizational citizenship behaviors, organizational commitment, job satisfaction, trust, turnover intentions, and job performance (Cohen-Charash \& Spector, 2001; Colquitt et al., 2001; Nowakowski \& Conlon, 2005; Erkutlu, 2011; Whitman, Caleo, Carpenter, Horner, \& Bernerth, 2012; Crow, Lee, \& Joo, 2012; Afari \& Elanain, 2014). The paradigm is also used to formulate ideas around the design of management policies such as employee voice and 
employee engagement, or to help formulate key practices such as appraisal and performance management systems. It is used to think about the provision of access to important organizational resources, such as career systems, or information.

\section{Hidden Structures That Preclude the Option For Real Fairness}

However, despite the insightful findings from these studies, there are still many limitations in our understanding of the processes through which fairness judgements are made. We have an incomplete understanding of the way in which employees, especially in today's world, make judgements about fairness. The question of how justice judgements are formed is still considered to be unresolved (Blader \& Tyler, 2013) and there is sparse research into how justice judgements are actually formed. This limits our understanding, especially in a context of significant social change. There is increasing transparency around what happens inside organizations, but also more vociferous social judgment. Moreover, individuals make judgements about fairness not just as employees, but as consumers, parents and citizens. The organizational justice literature does not consider the psychological dynamics underlying the relationship between justice and individuals subsequent attitudes and behaviours. Scholars have noted that models of justice need much better articulation of: the cognitive and emotional processes by which fairness judgements are formulated (Crawshaw et al., 2013), the processes that come into play in the theories of justice as described by Cropanzano et al., (2001), and the psychological processes that underlie the effects of justice (Blader \& Tyler, 2013).

A central problem with traditional organizational justice research is that it understates the importance of situations where employees are not equally placed to realise their human capabilities, due to barriers arising from structural inequalities (such as class, race, disability, gender and sexual oppression). In such contexts, not only are the cognitive and emotional 
judgements that lead to perceptions of fairness more complex than suggested by organizational justice paradigm, but HR policy responses also have to be broadened. Policy therefore has to intervene to provide the additional assistance some people may require to develop their capabilities and to be transformed. In order to be 'fair', policies have to make opportunities 'real' and feasible, in two ways: they have to ensure access to valued resources in order to give people the substantive freedoms to transform their potential capability; and they have to help make this 'conversion' easier. It is not just a case of putting people into the positions (for example using positive discrimination). You have to ensure people have the holistic opportunity to cope with all the other factors that enable success - there must be no hidden systemic barriers.

\section{Capability Theory}

A second fairness paradigm for HRM researchers to consider then is the capability approach (CA), originally developed by Sen (1999) in Development as Freedom and extended by Nussbaum $(2000,2001)$. This paradigm is fairly common in much social policy research, but is surprisingly rarely evidenced in HRM research.

We briefly lay out the core elements of this perspective in order to explain its principles, and then use the example of women on boards to signal its relevance to HRM research and several aspects of organizational effectiveness. The concept of 'capability' suggests that the wellbeing of the members of a given group should be evaluated by reference to their capacity to achieve a set of subjectively valued states or activities, 'functionings', through which their potential, not just as economic agents but also as citizens, can be realised (Sen, 1999). Departing from utilitarianism and rational choice theory, the Capability Approach's central tenet is that the end of development should be conceptualised in terms of 
individuals' capabilities to achieve a range of subjectively defined functionings. Thus a 'capability' refers to the effective opportunities which a given individual has to undertake, with the resources or commodities that they command, the actions and activities they choose to engage in. The CA identifies a range of 'conversion factors' through which resources or commodities can be transformed into 'capabilities' in this sense. Conversion factors can be derived from aspects of the physical or natural environment, but they may also be found in organizational and institutional dimensions of societal structures (Robeyns, 2005).

Thus the capability approach provides a normative framework for judging the effectiveness of institutional mechanisms (and the HR function and its policies is one such mechanism) in terms of how far they extend the substantive freedom of action of individuals. Essentially CA addresses central enlightenment themes about how to judge human progress, how to reconcile liberty and justice, and how to take account of both procedural and substantive requirements for ensuring social justice. CA does not imply these are easy issues to reconcile, but there is an in-built optimism about the possibilities for rational action and achieving fair results (Carpenter, 2009). More importantly, CA recognises that people are not equally placed to realise their human capabilities, due to barriers arising from structural inequalities of class, "race", disability gender and sexual oppression (Carpenter, 2009).

We argue that the theory needs to be mainstreamed and applied not just in social policy research but moved more centrally into the HRM literature. For example, it is possible to apply capability theory to the 'women of boards' debate. Based on merit alone, there should be many more women represented. However, it is not just the outcome (for example, the percentage of boards who are women) that can be used as a measure of fairness; it is also their access to, and treatment by, a range of HR processes (selection, potential assessment, promotion, development). Many organizations rely too much on the 'representation' measure, and too little on the 'process' measure. Despite the multifaceted nature of positive 
discrimination, the emancipation of women from systemic injustices justifies the application of a human rights approach to intervening robustly. The capabilities approach looks at all the factors that thwart women's progression and serve to intervene through policy to ensure fairer access to resources and enhance their ability to translate this access and opportunities into desired outcomes. We believe that Capability theory has considerable relevance to many areas of HRM. Its attention on the requisite capacities needed to achieve a set of subjectively valued states or activities, the functionings of individuals implicit in the creation of such capacity, critical questioning about what really represents effective opportunities and resources, and importance given to the conversion activities that must underpin any attempts to improve organizational effectiveness we would argue apply to a number of areas of current interest of research and practice. These questions are particularly important for issues such as diversity (for example equal opportunities), discrimination (for example age, gender, sexual orientation, disability, race discrimination), positive discrimination policies and practices (for example women on boards), the HRM aspects of corporate social responsibility issues (for example child labour, wage exploitation, fair trade and supply chain standards and social mobility).

Game Theory and Tournament Theory

Another of the criticisms levelled against HR functions, beyond adopting too narrow and individual a paradigm when thinking about fairness, has been their apparent inability to influence importance power structures in organizations, thereby allowing institutional forces to create contrary signals to much of their agendas. An example of such critique would be questions being raised about the design of legitimate executive bonuses and rewards incentives. This is another context where there may be hidden structures or unfairnesses that actually mean that the 'game' is in reality not fair. We use Game theory and Tournament 
theory, popular in economics research about rewards and incentives, to suggest new avenues for HRM research on fairness.

Tournament theory is used in the field of personnel economics to describe certain situations where wage differences are based not on marginal productivity but instead upon relative differences between the individuals (Eriksson, 2009). This theory was invented by economists Edward Lazear and Sherwin Rosen in their 1981 paper 'Rank-Order Tournaments as Optimum Labor Contracts'. They used tournament theory to look at performance related pay. Tournament theory is underwritten by the following assumptions. First, performance is hard to quantify, and therefore rewards like promotions and raises are decided more by luck than by qualifications or results. Second, since rewards are mostly based on luck, they need to be big or people will not want to work hard to get them. Third, overpaying executives motivates others to work hard because they can rise to the same position. Finally, a tournament system is good in cultural terms for the company.

Akerlof and Holden (2012) note that the concept of tournaments, in which relative output and not absolute output determine reward or punishment, have been used to explain many features of firms (and their HRM) associated with organizational effectiveness. There is an implicit prize structure associated within a number of inducement structures, such as within-firm job promotions, wage increases, bonuses, and CEO compensation, and the operation of an efficient market for scarce and valuable executive talent, or with "punishments" such as firings and up-or-out policies. Optimal tournaments typically punish more than they reward, and the prize structure depends crucially upon the distribution of the shocks to the output of organizational actors, the tournament spread (prize differential).

However, despite early attention from HRM researchers (Becker and Huselid, 1992) the development and application of this theory has been left to economists. Becker and Huselid (1992) conducted one of the first empirical assessments of incentives and prize differentials 
in the auto racing sector. They found that differentials did have incentive effects on individual performance and driver safety, that these effects peaked when there were higher spreads, but that incentive effects diminished as the spread increased, and the prize distribution had little influence on individual driver performance. Since then most of the research has been conducted outside of HRM, with sporadic attention to important issues, such as Conyon, Peck and Sadler's analysis (2001) of the internal structure of compensation and wage setting in the boardroom and executive incentives, or Siegel and Hambrick's (2005) analysis of vertical pay disparities in executive compensation and horizontal disparities among peers on firmwide collaborations as opposed to individual or subunit achievements. One of the reasons potentially that HRM researchers might be blinded to the best way to deal with this area of policy is that the theories and models that are used to justify 'fairness' by the internal actors who shape policy come from the field of economics and philosophy. More critical arguments seem to have come from a corporate governance and legal perspective, with recent arguments that management-dominated boards have passively allowed powerful executives to extract rent in the form of excessive compensation or perks at the expense of shareholders (Elson and Ferrere, 2013) or that ex ante incentive contracts suppress unselfish prosocial behavior resulting in inefficiencies to the detriment of organizational effectiveness (Stout, 2014).

Another theory that HRM researchers could engage with is Game theory. This is the study of mathematical models of conflict and cooperation between intelligent rational decision-makers (Myerson, 1991). One of the first formal works on game theory is the article of the logician Zermelo. However, the groundbreaking work by von Neumann (1928) on zero-sum games was one of the first articles that brought the game theory to light. This article was the basis for the book Theory of Games and Economic Behaviour by John von Neumann and Oskar Morgenstern (1944; 1947), by many regarded as the starting point of the game 
theory (Peters, 2008). In this book, the author extended von Neumann's work on zero-sum games and laid the groundwork for the study of cooperative (coalitional) games (Dimand \& Dimand, 1996). Although developed by economists, game theory has been utilized by mathematicians and scholars from other disciplines. For example, in the fifties and sixties, the further development of game theory was mainly the domain of mathematicians (Peters, 2008), such as Nash's (1950; 1951) work on the Nash equilibrium and on bargaining; Shapley's (1953) work on the Shapley value and the core for games with transferable quality; and the work of Kuhn and Tucker $(1950 ; 1953)$. More recently, game theory has been used in political science, psychology, as well as logic and biology. Its application ranges from strategic questions in warfare to understanding economic competition, from economic or social problems of fair distribution to behaviour of animals in competitive situations, and from parlour games to political voting systems (Peters, 2008).

Despite early consideration of the need to incorporate fairness into game theory (Rabin, 1993), again, it is interesting that it has been left to legal and corporate governance researchers to use game theory to understand strategic interactions within the firm or between the firm and other actors, with for example studies of inducements through the threat of legislation rather than actual legislation, and the possession of possession of asymmetric information, on organizational behaviour (Halfteck, 2008), socially responsible buying and sourcing applied to the acquisition of human talent (Bouchet, Troilo and Spaniel, 2015), and unprincipled behaviour and agent misconduct in corporate governance reform (Arce, 2015).

Both these theories may be used to identify the typical rules or strategems that 'players in the game' likely wish to follow and the fall-back positions taken. Popular with behavioural economists, they can be used to predict the behaviours that are seen as breaking the rules, and the rational and emotional responses that might likely follow. Game theory is applicable to a wide range of behavioral relations. For example, when the demands or desires 
of one party are in conflict with those of another - be it a divorce, a labour-management negotiation, or an international dispute - no one wants to be treated unfairly. With the increasing number of disputes either within or about organizations, it is worth considering how mathematics (e.g. Game theory) might help in the search for procedures that can ensure fair and equitable resolutions of such conflicts. Research has shown the relevance of game theory in solving the issues of fairness in the distribution of goods and conflict resolution. For example many Negotiation Support Systems such as Adjusted-Winner (Brams \& Taylor 1996), Smart-settle (Thiessen \& McMahon 2000) and Family-Winner use bargaining and game theory to provide win-win solutions to participants in disputes (Abrahams, Bellucci \& Zeleznikow, 2012). The applicability of these two theories within the HRM domain is potentially broad. A number of questions might be addressed when using game theory in relation to executive pay: what is fair pay in today's corporate world? What is socially just reward? What creates imbalanced, dysfunctional or socially harmful incentives? By applying this theory, it would be possible to assess how specific stakeholders, or identities, impact such assessments. It could further be used to identify the typical rules or stratagems that 'players in the game' will likely first wish to follow, and the fall-back positions taken. This paradigm could be used to assess whether the game theory assumptions (the integrity of the game) are considered to have been fairly met, if such judgements differ across stakeholder groups, whether individuals as employees versus individuals as consumers make similar judgements of fairness. It could be used to establish or predict the behaviours that are seen as breaking the rules, of interest to regulators and behavioural economists, and the rational and emotional responses that might likely follow.

Tournament theory could also help streamline understanding of the fairness/ unfairness of pay systems in general, and not just elite rewards. Pay in a number of economies is now seen to be unevenly distributed, and the gap between the top $1 \%$ and the 
rest of the population has been widening steadily over the last decade. Substantial and growing pay inequality poses a serious challenge to society and government, and various reviews, such as the Hutton Review of Fair Pay in the UK, have taken place (Hutton 2010). How might we address whether it is fair in this domain? Do high-earners deserve such large rewards, and how might acceptable differentials be argued? In making decisions on pay, managers note that fairness cannot be understood as simply about equality of outcomes. In practice we make judgements about an individual's 'due dessert', and this will vary according to their differing contributions and choices, and the way in which the influence of chance and external circumstances has been minimised. Fairness also requires that processes as well as outcomes must be fair. Fair pay must therefore be proportional to an individual's contribution and set by fair pay determination processes. The value of individuals' contributions will reflect both the weight of their particular posts and their actions and efforts within them. Some form of proportionality of treatment - whether in respect of need, or merit, or a mixture of both, implies limits on pay dispersion. A maximum pay multiple would be one mechanism for maintaining those limits. As well as being morally desirable, fair pay brings instrumental benefits to organizations by supporting greater employee engagement and morale, and to society as a whole by helping to avoid inequality traps and assisting social mobility and incentives to productive work.

\section{New Variables and Dimensions Being Added to the Consideration of Fairness and Organizational Justice}

If the first research problem is to better understand how justice judgements are formed, and the cognitive and emotional processes through which fairness judgements are formulated and that underlie its effects, then the second is to understand some of the new variables that should now be added to our considerations of organizational justice. Over the past decade or 
two, the generational gap within organizations has become more prevalent, maybe due to the aging population. Workplaces are becoming increasingly age diverse (Cogin, 2012), and HR managers are beginning to understand that the differences in generations could have an impact on the effectiveness of the organization. They are now being forced to ask challenging questions of their HR policy. How do we ensure fairness from one generation to another by fairly passing the baton from one to another over time? What do we owe to people who don't yet exist, or to the future existence of those who are now born? These questions feature not just in the use of sovereign funds and how to deal with levels of debt (national, corporate, personal), but in many aspects of HRM policy, such as discussions about pension funds, corporate social responsibility, corporate governance and the long-term viability of the organization, sustainable business models, and human rights.

In short, it is bow evident that we need to see organizational justice through a Temporal Perspective if we are to better understand how concepts of fairness might be applicable, or become challenged, over time. Once more, HRM researchers could co-opt theory from some other disciplines. A temporal paradigm has come from either a legal perspective (with attention to how to avoid irretrievably compromising implicit rights and obligations embedded in constitutions or other legal instruments over time) or from an environmental management perspective (through attention to provision of the same resources, access to these resources, and the same freedoms of choice and action across generations i.e. avoiding borrowing against someone else's future?). There are two component theories that have come to dominate the temporal paradigm: inter-generational equity; and burden sharing.

Intergenerational Fairness has its roots in John Rawls book, A Theory of Justice (1971) in which one of the subjects dealt with was justice between the generations. Rawls reflects on the original position from the perspective of multiple generations, and discusses intergenerational justice under the aspect of the "just savings" principle, whereby capital 
accumulation serves the purpose of establishing and maintaining a just system over time. Rawls (1971) views intergenerational equity as a policy issue necessitating governmental intervention to manage "social saving and investment" for the benefit of the least advantaged generation. In his 1923 essay on the Problem of Generations Karl Mannheim defined a generation as a group that shares both a particular span of birth years and a set of worldviews grounded in defining social or historical events that have occurred during the generation's formative development years (Mannheim, 1952). A generation is also defined as a 'group of people or cohorts who share birth years and experiences as they move through time together, influencing and being influenced by a variety of critical factors (Brown-Weiss, 1989). These factors include shifts in society wide attitudes, changes in social, economic and public policy and major events.. According to Mannheim, generational cohorts share a common consciousness and develop collective ideas, slogans, and experiences.

Studies suggest that today's workforce includes at least four generations spanning more than 60 years in age: Traditionalists, Baby Boomers, Generation X, and Generation Y (Smola and Sutton 2002; Wallace 2006); there are differences in expectations, values and motivators across generational cohorts (e.g. Smith and Clurman, 1997; Stelzl and Seligman, 2009; Twenge, Campbell, Hoffman and Lance, 2010); and that in today's workplace, the likelihood that an older employee will report to a younger manager is increasing (Cogin, 2012). Supporters of the notion of multigenerational theory argue that people who grow up in different time periods have very different sets of beliefs, values, attitudes, and expectations, which in turn impact their behaviour generally and in the workplace (Inglehart 1997; Glass 2007). There are of course many criticisms that can be levelled at simply using age cohort as a proxy for generation and there is continued debate within the HRM literature about the power of generations as an explanatory variable. On the one hand Costanza, Badger, Fraser, Severt and Gade (2012) argue that whilst generational differences can be 
observed in attitudes and values (and they are generally easy to find), they can be explained by way of being explained by life stages and general maturation. Their meta-analysis of generational differences on three work-related criteria of job satisfaction, organizational commitment, and intent to turnover found only moderate to small relationships. Against this Cogin (2012) found generational differences in protestant work ethic when the effects of culture (country) and life stage were controlled for, and Susaeta, Pin, Idrovo, Espejo, Belizón, Gallifa, Aguirre and Pedrozo (2013) found significant differences between generations and cultures, particularly when focusing on the life project.

This has led to a second perspective which has potential implications for fairness, which is Burden sharing. Political sociology identifies two principal approaches to burdensharing, one based on a 'logic of expected consequences' (informed by a cost-benefit rationale) and the other based on a 'logic of appropriateness' (informed by a norm-based rationale) (March and Olsen, 1998). On this basis, some of the most important issues in society today affect multiple generations of people in ways not seen before such that intergenerational relations may now be conducted in ways in which the interests of present and future generations are not always aligned. This perspective on intergenerational fairness based on ideas of sustainable development, defined as development that meets the needs of the present without compromising the ability of future generations to meet their own needs. It has mainly been looked at within the context of climate change and environmental sustainability, arguing that future generations of people may endure much of the burden from major global-scale changes in the environment involving delayed effects (such as ozone depletion, species extinction, and global warming) while gaining minimal benefits from and contributing little (or not at all) to the creation of such problems (Wade-Benzoni, Hernandez, Medvec \& Messick, 2008). However, recent issues within organizations such as pension provision, questions of reward, careers across different age groups, global sourcing of work, 
social mobility etc., have impacts across generational groups and across different internal employee segments and are becoming more important.

A good example of a topical HR issue which a temporal paradigm can help us understand is that of pensions. When asking whether the Baby Boom generation should pay more for their pensions surfaces problems of intergenerational fairness, the fundamental issue is one of the distribution of the burdens of population ageing, lower fertility rates, rising life expectancy, and how we face up to the financial consequences. It is not just whether we can redistribute the costs more equitably, but how we do this, and whether we can look at which generation bears the cost of one part of the problem (for example ageing and pensions) without looking at another (for example fertility rates). If the costs of pension promises made to sets of individuals historically, and at the time on a basis to be considered legitimate, are to be met in full, what are the adjustments to be made? Given it is important that pensions are sustainable and affordable over the long term, an intergenerational 'lens' on 'fairness' triggers the following sorts of questions that need resolving: societally: how can we be reassured that shared costs and contributions are being contained, that the revenues taken from current and future contributors used to fund a pay-as-you-go pension benefit, match the pension benefits of the no-longer contributors? Is the degree and balance of fairness between the employee and the taxpayer based on sustainable principles over time? Are we paying fairly for the benefits that are being offered? If we withdraw these benefits, are we being fairer to the next generation or denying them rights their predecessors fought for?

\section{Equity Sensitivity Theory}

Inter-generational equity research, then, argues that we may infer intergenerational differences in both the perception and interpretation of fairness, i.e. the way in which people 
from one generation perceive fairness, and that this may well impact the cognitive and emotional responses associated with this. Somewhat related to this perspective of different framing across generations is the notion that such differences in framing are in fact more of an individual difference and that organizational justice research over-generalizes responses to inequity. Equity Sensitivity is defined as the personality trait by means of which individuals calculate their outcome/input ratios and compare them to those of others (Huseman et al., 1987). Equity sensitivity originated from Adams (1965) equity theory. According to equity theory, as individuals and as employees, we are concerned with how much we get (outcomes) in proportion to how much we contribute (inputs). We then compare this ratio with that of another individual to determine whether the situation is equitable. When things are inequitable and the ratios are unequal, we are motivated to bring this equation back into balance (Taylor, Kluemper \& Sauley, 2009). Despite the widespread acceptance and application of Adams's theory, Huseman et al. (1985) were among the first to challenge its basic tenets. They questioned the notion that all individuals are equally sensitive to equity. Rather, they believed that individuals have different perceptions of and reactions to inequity. Consequently, Huseman and colleagues classified individuals into one of three categories based on their preferences for equity: Benevolents, Entitleds, and Equity Sensitives.

Such observations drive many of our assumptions about what creates employee engagement and is used to think about employee segmentation - and also how organizations will create and then market different and individualised sets of rewards and benefits to groups of employees in return for their performance at the workplace - called 'employee value propositions'. The concept of 'equity sensitivity' suggests significant differences in individual notions of fairness, and distinguishes between 'benevolents' (givers) and 'entitleds' (takers). Huseman et al. (1987) expounded the equity sensitivity construct, which “...suggests that individuals react in consistent but individually different ways to both 
perceived equity and inequity because they have different preferences for (i.e., are differentially sensitive to) equity"” (p. 223). Individuals do not necessarily share similar interpretations of fairness and justice; however, their interpretations are based on which category they fall under. Members of the equity sensitive group are presumed to follow the precepts of classical equity theory (Adams, 1963), which proposes that individuals assess the ratio of their outcomes from and inputs to a relationship against those of comparison other. If these ratios are seen as unequal, inequity exists (Mudrack, Mason \& Stepanski, 1999). Unlike, equity sensitives, benevolents and entitleds may be attracted to situations with unequal outcomes-to-inputs ratios, and thus not adhere to an equity norm (Mudrack et al., 1999). Benevolents are 'givers' who relatively are untroubled by unfair treatment and may be content with little return for their inputs. Entitleds, in contrast are 'takers'. They seek a better deal than other and may incorporate a broad array of strategies such as shyness, charm, temper or intimidation to get their way (Husemam et al., 1987)

The importance of equity sensitivity may be enhanced in ambiguous contexts in which the definition of suitable behaviour is somewhat unclear (cf. Greenberg, 1990). Ambiguity, or even conflict as to what is ethically appropriate seems to characterise an increasing number of organizations and their constituents, thus pointing to the key role of equity sensitivity in shaping responses in situations possessing ethnical overtones (Mudrack et al., 1999).

\section{Conclusions and Directions for Future Research}

Employees use several everyday words to mean the same as fairness - equitable, impartial, unprejudiced, unbiased, objective and dispassionate. They may disagree about whether something is fair or not - they may see it differently - but that is not necessarily the 
same as the situation actually being fair or unfair. It is difficult to equate fairness with justice, or either of these with moral rightness. HR professionals face two problems: their actions may be good for some people but bad for others; and some actions which are required by certain duties or rights may still harm (in a general sense) some people. Whatever solution that HR professionals arrive at may be perceived to be fair to some but unfair to others, hence the temptation to fall back on what is perceived to be the most "reasonable" solution, which is to have some kind of equitable (impartial and just) decision process - fair to all parties in that it is dictated by reason, conscience and conformity to legitimate rules or standards.

Traditionally HRM scholars have used an organizational justice paradigm to deal with this. However, debates around a number of issues that are important to HRM researchers such as reform of pensions, the sharing of job opportunities and the quality of work across generational groups, balancing rewards and incentivisation of senior leaders with the delivery of valued performance, the shape of talent investments across global boundaries, the number of women at board level and use of quotas, and so forth - demonstrates the importance both of the need to understand and incorporate hidden dimensions to fairness into our research, as well as some novel and additional variables. As such, we believe that research into fairness, and an understanding of its consequences for organizational effectiveness, needs now to become more cross-disciplinary.

In laying out the complexities of fairness, and the need now to move beyond the organizational justice paradigm that has dominated much HRM research, we have laid out a range of ideas from across a range of disciplines. Our argument rests on the assumption that individual judgments about fairness, and understanding the contexts on which such judgments are based, will increasingly matter. Whilst fairness is subjective, we need to deconstruct how people are framing their judgments of fairness, if we are to have a better 
chance of managing and shaping positive outcomes at the individual and organizational level. By constructing debate more openly in ways that acknowledges different frames for fairness, should result in more positive (or less harmful) individual and organizational level outcomes. We do not argue that fairness should be seen as an outcome in HRM research. It is rather best viewed as a cognitive frame to serve as an input to organizational decision making and judgements about organizational effectiveness. The research and managerial task at hand is to examine whether the quality of this decision making may be improved by examining the cognitive process behind unfairness judgments, the frames deployed, and whether particular contexts or subjects We need better understanding of the judgment processes in action. Reference to a cognitive process within the assessment of fairness, and the use of our fairness framework in this context, should make possible a more balanced but realistic conversation about the source of potential feelings of unfairness.

\section{References}

Abrahams, B., Bellucci, E., \& Zeleznikow, J. (2012), "Incorporating fairness into development of an integrated multi-agent online dispute resolution environment", Group Decision and Negotiation, Vol. 21 No. 1, pp. 3-28.

Adams, J. S. (1965), "Inequity in social exchange", in Berkowitz, L. (Ed.), Advances in experimental social psychology Volume 2, New York: Academic Press. pp. 267-299

Adams, J.S. (1963), “Toward an understanding of inequity”, Journal of Abnormal and Social Psychology, Vol. 67 No. 5, pp. 422-36.

Akerlof, R. J. and Holden, R. T. (2012), “The nature of tournaments”, Economic Theory, Vol. 51, pp. 289-313. 
Al Afari, T.S. and Elanain, H.M.A. (2014), "Procedural and distributive justice as mediators of the relationship between interactional justice and work outcomes: an empirical study of the UAE public health care sector", Journal of Applied Business Research, Vol. 30 No. 4, pp. 1091-1107.

Ambrose M. L. (2002), “Contemporary justice research: A new look at familiar questions”, Organizational Behavior and Human Decision Processes, Vol. 89 , No. 1, pp. 803-812.

Ambrose, M. L., and Arnaud, A. (2005), “Are procedural justice and distributive justice conceptually distinct?”, in Greenberg, J. \& Colquitt, J.A. (Eds.), Handbook of organizational justice, Mahwah, NJ: Lawrence Erlbaum, pp. 59-84.

Arce, D. G. (2015), “Integrity, unprincipled agents and corporate governance reform", European Journal of Law and Economics, Vol. 39:, pp.539-551.

Becker, B. E. and Huselid, M. A. (1992), “The incentive effects of tournament compensation systems”, Administrative Science Quarterly, Vol. 37, No. 2, 336-350.

Bies, R. J., and Moag, J. F. (1986), "Interactional justice: Communication criteria of fairness", in Lewicki, R.J., Sheppard,B.H. \& Bazerman, M.H. (Eds.), Research on negotiations in organizations Volume 1, Greenwich, CT: JAI Press, pp. 43-55.

Blader, S. L. and Tyler, T. R. (2003), “A four component model of procedural justice: Defining the meaning of a "fair" process", Personality and Social Psychology Bulletin, Vol. 29, pp. 747-758.

Blader, S. L., and Tyler, T. R. (2005), "How can theories of organizational justice explain the effects of fairness?", in Greenberg, J. \& Colquitt, J.A. (Eds.), Handbook of organizational justice, Mahwah, NJ: Lawrence Erlbaum, pp. 329-354. 
Bouchet, A., Troilo, M., and Spaniel, W. (2015), "International sourcing, social responsibility, and human assets: a framework for labor procurement negotiations in baseball's talent supply chain", Corporate Governance, Vol. 15 No. 2, pp. 228-214.

Brams, S. J., and Taylor, A. D. (1996), Fair Division: From Cake-Cutting to Dispute Resolution, Cambridge University Press, Cambridge.

Brown-Weiss, E (1989), In Fairness to Future Generations: International Law, Common Patrimony and Intergenerational Equity, Dobbs Ferry, NY: Transitional Publishers, Inc.

Carpenter, M. (2009), “The capabilities approach and critical social policy: lessons from the majority world?", Critical Social Policy, Vol. 29 No. 3, pp. 351-73.

Chou, R. J-A. (2009), “Organizational justice and turnover intention: A study of direct care workers in assisted living facilities for older adults in the United States", Social Development Issues, Vol. 31 No. 1, pp. 69-85.

Cogin, J. (2012), “Are generational differences in work values fact or fiction? Multi-country evidence and implications", International Journal of Human Resource Management, Vol. 23 No. 11, pp. 2268-2294.

Cohen-Charash, Y. and Spector, P. (2001), "The role of justice in organizations: A metaanalysis”, Organizational Behavior and Human Decision Processes, Vol. 86 No. 2, pp. $278-$ 321.

Colquitt J. A. (2001), “On the dimensionality of organizational justice: a construct validation of a measure", Journal of Applied Psychology, Vol. 86, pp. 386-400.

Colquitt, J. A., Conlon, D. E., Wesson, M. J., Porter, C. O. L. H., and Ng, K. Y. (2001), "Justice at the millennium: A meta-analytic review of 25 years of organizational justice research", Journal of Applied Psychology, Vol. 86, pp. 425-445. 
Colquitt, J. A., Greenberg, J., and Scott, B. A. (2005), “Organizational justice: Where do we stand?”, In Greenberg, J. \& Colquitt, J.A. (Eds.), Handbook of organizational justice. London: Erlbaum, pp. 589-620.

Conyon, M. J., Peck, S. I. and Sadler, G. V. (2001), “Corporate tournaments and executive compensation: evidence from the UK", Strategic Management Journal, Vol. 22, pp. 805815.

Costanza, D.P., Badger, J.M., Fraser, R.L., Severt, J.B., and Gade, P.B. (2012), "Generational Differences in Work-Related Attitudes: A Meta-analysis", Journal of Business Psychology, Vol. 27, pp. 375-394.

Crawshaw, J. R., Cropanzano, R., Bell, C. M., Nadisic, T. (2013), “Organizational justice: New insights from behavioural ethics", Human Relations, Vol. 66, pp. 885-904.

Crawshaw, J. R., Van Dick, R. and Brodbeck, F. C. (2012), “Opportunity, fair process and relationship value: Career development as a driver of proactive work behavior", Human Resource Management Journal, Vol. 22 , No. 1, pp. 4-20.

Cropanzano, R. and Greenberg, J. (1997), "Progress in organizational justice: Tunnelling through the maze", in Cooper, C. and Robertson, I. (eds.) International Review of Industrial and Organizational Psychology, Volume 12, Chichester: Wiley \& Sons Ltd, pp. 317-372.

Cropanzano, R., Byrne, Z. S., Bobocel, D. R. and Rupp, D. E. (2001), "Moral virtues, fairness heuristics, social entities, and other denizens of organizational justice", Journal of Vocational Behavior, Vol. 58 No. 2, pp. 164-209.

Cropanzano, R., Prehar, C. A., \& Chen, P. Y. (2002), "Using social exchange theory to distinguish procedural from interactional justice", Group and Organizational Management, Vol. 27, pp. 324-351. 
Crow, M. S., Lee, C., and Joo, J. (2012), “Organizational justice and organizational commitment among South Korean police officers", Policing: An International Journal of Police Strategies and Management, Vol. 35 No. 2, pp. 402-423.

De Cremer, D. (2005), "Procedural and distributive justice effects moderated by organizational identification.”, Journal of Managerial Psychology, Vol. 20 No. 1, pp. 4-13.

Deutsch, M. (1975), "Equity, equality and need: What determines which value will be used as the basis for distributive justice?", Journal of Social Issues, Vol. 31 No. 3, pp. 137-149.

Dimand, M.A. and Dimand, R.W. (1996), A history of game theory, volume 1: from the beginnings to 1945, London: Routledge.

Elson, C. M. and Ferrere, C. (2013), "Executive superstars, peer groups, and overcompensation: cause, effect and solution", Journal of Corporation Law, Vol. 38 No. 3, pp. 487-531.

Eriksson, T. (2009), "Tournaments", in Durlauf, S.N. and Blume L.E. (eds.), The New Palgrave Dictionary of Economics. Online edition, Basingstoke: Palgrave Macmillan. Lazear, E.P. and Rosen, S. (1981), "Rank-order tournaments as optimum labor contracts", Journal of Political Economy, Vol. 89 No. 5, pp. 841-64.

Erkutlu, H. (2011), "The moderating role of organizational culture in the relationship between organizational justice and organizational citizenship behaviors", Leadership and Organization Development Journal, Vol. 32 No. 6, pp. 532-554.

Folger, R. (1977), "Distributive and procedural justice: Combined impact of "voice" and improvement on experienced inequity", Journal of Personality and Social Psychology, Vol. 35, pp.108-119.

Folger, R. and Cropanzano, R. (1998), Organizational Justice and Human Resource Management, London: Sage. 
Folger, R. and Cropanzano, R. (2001), "Fairness theory", in Greenberg J and Cropanzano R (eds.), Advances in Organizational Justice. Stanford, CA: Stanford University Press, pp. 153.

Folger, R., and Lewis, D. (1993), "Self-appraisal and fairness in evaluations”, in Cropanzano, R. (Ed.), Justice in the workplace: Approaching fairness in human resource management. Hillsdale, NJ: Lawrence Erlbaum. pp. 107-131.

Greenberg J. (1993), “The social side of fairness: interpersonal and informational classes of organizational justice", in Cropanzano, R. (ed.), Justice in the Workplace: Approaching Fairness in Human Resource Management, Hillsdale, NJ: Erlbaum, pp. 79-103.

Greenberg, J. (1986), "Determinants of perceived fairness of performance evaluations", Journal of Applied Psychology, Vol. 71, pp.340-342.

Greenberg, J. (1987a), "Reactions to procedural injustice in payment distributions: Do the ends justify the means?", Journal of Applied Psychology, Vol. 72, pp.55-61.

Greenberg, J. (1987b), "Using diaries to promote procedural justice in performance evaluations', Social Justice Research, Vol. 1, pp.219-234.

Greenberg, J. (1987c), “A taxonomy of organizational justice theories”, Academy of Management Review, Vol. 12, pp. 9-22.

Greenberg, J. (1990), “Organizational justice: yesterday, today, and tomorrow”, Journal of Management, Vol. 16, pp.399-432.

Greenberg, J. and Colquitt, J. A. (2005), Handbook of organizational justice, Mahwah, NJ: Lawrence Erlbaum. 
Griffeth, R. W., Hom, P. W., and Gaertner, S. (2000), “A meta-analysis of antecedents and correlates of employee turnover: Update, moderator tests, and research implications for the next millennium”, Journal of Management, Vol. 26, pp. 463-488.

Halfteck, G. (2008), “Legislative threats”, Stanford Law Review, Vol. 61 No. 3, pp. 629- 710.

Huseman, R.C., Hatfield, J.D. and Miles, E.W. (1987), “A new perspective on equity theory: the equity sensitivity construct", Academy of Management Review, Vol. 12 No. 2, pp. 22234.

Hutton, W. (2010), Hutton review of fair pay in the public sector, Interim report, London: HM Treasury.

Inglehart, R. (1997), Modernization and Postmodernization, Princeton University Press.

Kernan, M. C., and Hanges, P. J. (2002), "Survivor reactions to reorganization: Antecedents and consequences of procedural, interpersonal, and informational justice", Journal of Applied Psychology, Vol. 87 No. 5, pp. 916- 928.

Konovsky, M. (2000), “Understanding procedural justice and its impact on business organizations", Journal of Management, Vol. 26 No.3, pp. 489-511.

Kuhn, H.W. and Tucker, A.W. (1950), (eds) Contributions to the theory of games, volume I. Annals of Mathematics Studies, No 24. Princeton, NJ: Princeton University Press.

Kuhn, H.W. and Tucker, A.W. (1953), (eds) Contributions to the theory of games, volume II. Annals of Mathematics Studies, No 28. Princeton, NJ: Princeton University Press.

Landy, R. J., and Conte, J. M. (2004). Work in the 21st century, New York: McGraw Hill.

Leventhal, G. S. (1976), "The distribution of rewards and resources in groups and organizations", in Berkowitz, L. \& Walster, W. (Eds.), Advances in experimental social psychology Volume 9, New York: Academic Press, pp. 91-131. 
Leventhal, G. S. (1980), "What should be done with equity theory? New approaches to the study of fairness in social relationships", in Gergen, K., Greenberg, M. \& Willis, R. (Eds.), Social exchange: Advances in theory and research, New York: Plenum, pp. 27-55

Leventhal, G. S., Karuza, J., and Fry, W. R. (1980), "Beyond fairness: A theory of allocation preferences”, In Mikula, G. (Ed.), Justice and social interaction, New York: Springer-Verlag, pp. 167-218.

Lind, E. A. (1995), "Justice and authority relations in organizations", in Cropanzano R and Kacmar M.K. (eds) Organizational Politics, Justice, and Support: Managing the Social Climate of the Workplace, Westport, CT: Quorum Books, pp. 83-96.

Lind, E. A. (2001), "Fairness heuristics theory: Justice judgments as pivotal cognitions in organizational relations", in Greenberg, J. and Cropanzano, R. (eds.), Advances in Organizational Justice, Stanford, CA: Stanford University Press, pp. 56-88.

Lind, E. A., and Tyler, T. R. (1988), The social psychology of procedural justice, New York: Plenum.

Mannhein, K. (1952), “The Problem of Generations”, in Kecskemeti, P. (ed.), Essays on the Sociology of Knowledge by Karl Mannheim, New York: Routledge \& Kegan Paul.

March, J.G. and Olsen, J.P. (1989), Rediscovering institutions: the organizational basis of politics, New York: Free Press.

Meyer, J.P., and Smith, C.A. (2000), "HRM Practices and Organizational Commitment: Test of a Mediation Model", Canadian Journal of Administrative Sciences, Vol. 17, pp. 319-331. Morand, D. A., and Merriman, K. K. (2012), "Equality Theory as a Counterbalance to Equity Theory in Human Resource Management", Journal of Business Ethics, Vol. 111 No. 1, pp. $133-144$. 
Mudrack, P.E., Mason, E.S. and Stepanski, K. (1999), "Equity Sensitivity and Business Ethics”, Journal of Occupational and Organizational Psychology, Vol. 72 No. 4, pp. 539560.

Myerson, R.B. (1991), Game theory, analysis of conflict, Cambridge, MA: Harvard University Press.

Nash, J.F. (1950), “The bargaining problem”, Econometrica. Vol. 18 No. 2, pp.155-62.

Nash, J.F. (1951), "Non-cooperative games”, Annals of Mathematics, Vol. 54 No. 2, pp. 28695.

Nathan, B. P., Mohrman, A. M., Jr., and Milliman, J. (1991), "Interpersonal relations as a context for the effects of appraisal interviews on performance and satisfaction: A longitudinal study", Academy of Management Journal, Vol. 34, pp.352-369.

Nowakowski, J. M., and Conlon, D. E. (2005), “Organizational justice: Looking back, looking forward", The International Journal of Conflict Management, Vol. 16, pp. 2-49.

Nussbaum, M. (2001), Upheavals of thought: the intelligence of emotions, Cambridge New York: Cambridge University Press.

Nussbaum, M.C. (2000), Women and human development: the capabilities approach, Cambridge: Cambridge University Press.

Otaye, L. and Wong, W. (2014), "Mapping the contours of fairness: The impact of unfairness and leadership (in)action on job satisfaction, turnover intention and employer advocacy", Journal of Organizational Effectiveness: People and Performance, Vol. 1 No. 2, pp. 191-204. Paré, G., and Tremblay, M. (2007), “The Impact of Human Resource Management Practices on IT Personnel Commitment, Citizenship Behaviors, and Turnover Intentions”, Group and Organization Management, Vol. 37 No. 3, pp. 326-357. 
Peters, H. (2008), Game theory: A Multi-leveled approach, Springer Science \& Business Media.

Poon, J.M. (2012), “Distributive justice, procedural justice, affective commitment, and turnover intention: a mediation-moderation framework", Journal of Applied Social Psychology, Vol. 42 No. 6, pp. 1505-1532.

Rabin, M. (1993), “Incorporating fairness into game theory and economics.”,American Economic Review, Vol. 83 No. 5), pp.1281-1302.

Rawls, J. (1971), A theory of justice, Cambridge, MA: Belknap Press of Harvard University Press.

Robeyns, I. (2005), “The capability approach: a theoretical survey”, Journal of Human Development, Vol. 6 No.1, pp. 93-114.

Rupp, D. E., Shao, R., Jones, K., and Liao, H. (2014), “The utility of a multifoci approach to the study of organizational justice: A meta-analytic investigation into the consideration of normative rules, moral accountability, bandwidth-fidelity, and social exchange", Organizational Behavior and Human Decision Processes, Vol. 123, pp.159-185.

Sen, A. (1999), Development as freedom, Oxford: Oxford University Press.

Siegel, P. A. and Hambrick, D. C. (2005), "Pay Disparities Within Top Management Groups: Evidence of Harmful Effects on Performance of High-Technology Firms", Organization Science, Vol. 16 No. 3, pp.259-274.

Smith, J. W., \& Clurman, A. (1997), Rocking the Ages: The Yankelovich Report on Generational Marketing, New York: Harper Business.

Smola, K.W. and Sutton, C.D. (2002), “Generational differences: revisiting generational work values for the millennium”, Journal of Organizational Behavior, , Vol. 23, pp.363-382. 
Stelzl, M. and Seligman, C. (2009), "Multiplicity across cultures: multiple national identities and multiple value systems", Organization Studies, Vol. 30 No. 9, pp.959-973.

Stout, L. A. (2014), "Killing conscience: the unintended behavioral consequences of "pay for performance", Journal of Corporation Law, Vol. 39 No. 3, pp. 525-561.

Susaeta, L., Pin, J.R., Idrovo, S., Espejo, A., Belizón, M., Gallifa, A., Aguirre, M., and Pedrozo, E.A. (2013), “Generation or culture? Work attitude drivers: an analysis in Latin America and Iberian countries", Cross Cultural Management, Vol. 20 No. 3, pp.321-360.

Tabibnia, G., Satpute, A. B., and Lieberman, M. D. (2008), "The sunny side of fairness: Preference fairness activates reward circuitry (and disregarding unfairness activates selfcontrol circuitry)", Psychological Science, Vol. 19, pp. 339-347.

Taylor, S.G., Kluemper, D. \& Sauley, K.S. (2009), "Equity sensitivity revisited: contrasting unidimensional and multidimensional approaches", Journal of Business Psychology, Vol. 24, pp. 299-314.

Thibaut, J. W., and Walker, L. (1975), Procedural justice: A psychological perspective, Hillsdale, NJ: Erlbaum.

Thiessen, E. M. and McMahon, J. P. (2000), “Beyond Win-Win in Cyberspace”, Ohio State Journal on Dispute Resolution, Vol. 15, pp. 643.

Tremblay, M., Cloutier, J., Simard, G., Chenevert, D., and Vandenberghe, C. (2010), "The role of HRM practices, procedural justice, organizational support and trust in organizational commitment and in-role and extra-role performance", International Journal of Human Resource Management, Vol. 21, pp. 405-433.

Twenge, J.M., Campbell, S.M., Hoffman, B.J. and Lance, C.E. (2010), "Generational differences in work values: leisure and extrinsic values increasing, social and intrinsic values decreasing”, Journal of Management, Vol. 36 No. 5, pp. 1117-1142. 
Tyler, T. R., and Bies, R. J. (1990), "Beyond formal procedures: The interpersonal context of procedural justice", in Carroll, J.S. (Ed.), Applied social psychology in business settings. Hillsdale, NJ: Erlbaum, pp. 77-98.

Van den Bos, K. and Lind, E. A. (2002), "Uncertainty management by means of fairness judgments", Advances in Experimental Social Psychology, Vol. 34, pp.1-60.

Von Neumann, J. (1928), “Zur Theories der Gesellschaftsspiele, Mathematische Annalen”, 100, pp. 295-320. English translation by S. Bergmann in Luce, R.D. and Tucker, A.W. (eds.), Contributions to the Theory of Games IV (1959), Princeton U. Press, pp. 13-42,

von Neumann, J. and Morgenstern, O. (1944, 1947), Theory of games and economic behavior, $\square$ Princeton, NJ : $\square$ Princeton University Press.

Wade-Benzoni, K.A, Hernandez, M., Medvec, V., \& Messick, D. (2008), "In fairness to future generations: The role of egocentrism, uncertainty, power, and stewardship in judgments of intergenerational allocations", Journal of Experimental Social Psychology, Vol. 44, pp. 233-245.

Wallace, D. (2006), “Women's Time: Women, Age, and Intergenerational Relations in Doris Lessing's the Diaries of Jane Somers", Studies in the Literary Imagination, Vol. 39 No. 2, pp. 43-59.

Whitman, D. S., Caleo, S., Carpenter, N. C., Horner, M. T., and Bernerth, J. B. (2012), "Fairness at the collective level: A meta-analytic examination of organizational justice climate”, Journal of Applied Psychology, Vol. 97 No. 4, pp. 776-791.

Young, H. P. (1995), “The economics of convention”, Journal of Economic Perspectives, Vol. 10, pp.105-122. 
Figure 1: Conceptual Model of Fairness and Suggestions for Future Research

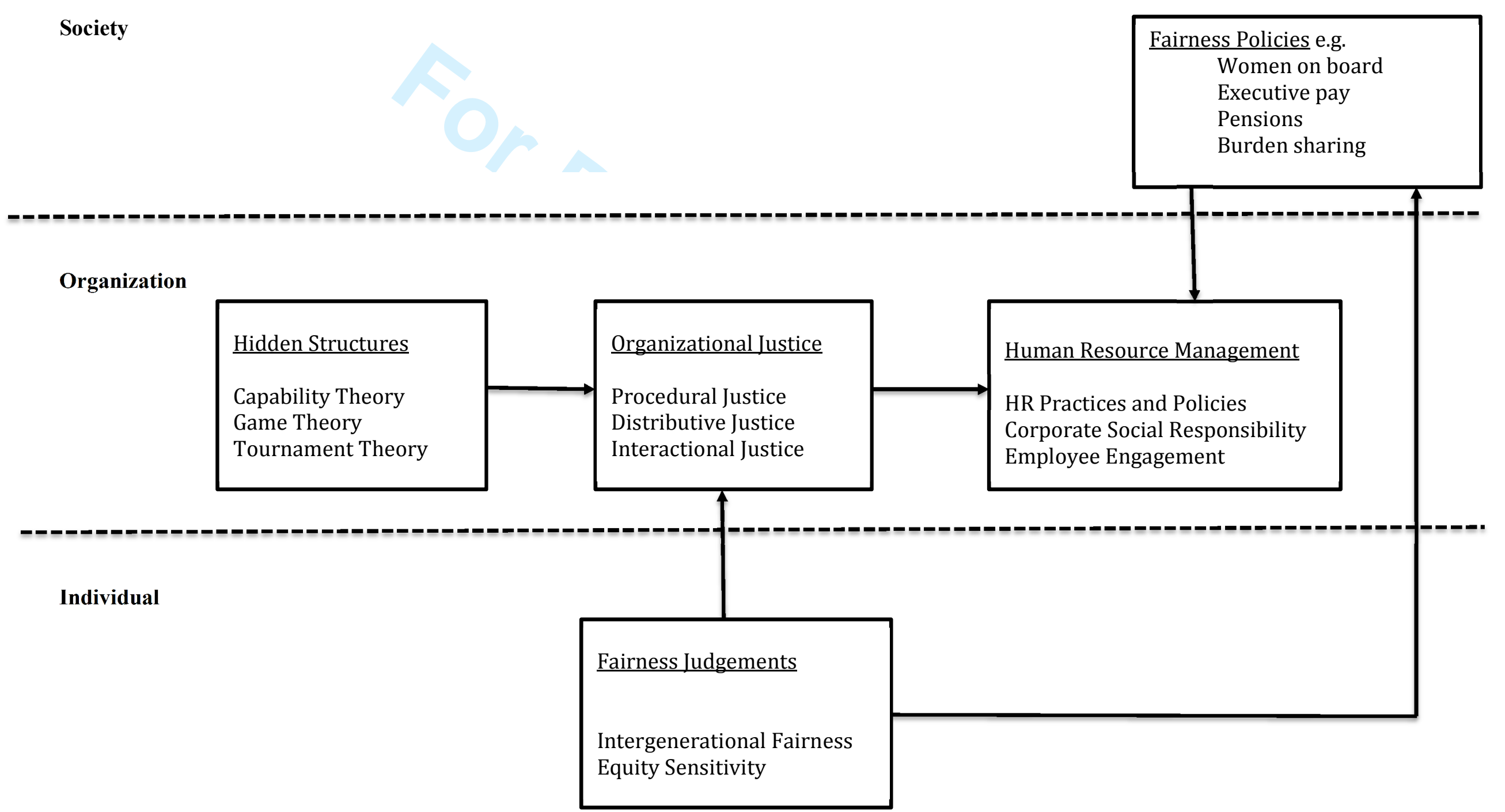


Figure 1: Conceptual Model of Fairness and Suggestions for Future Research

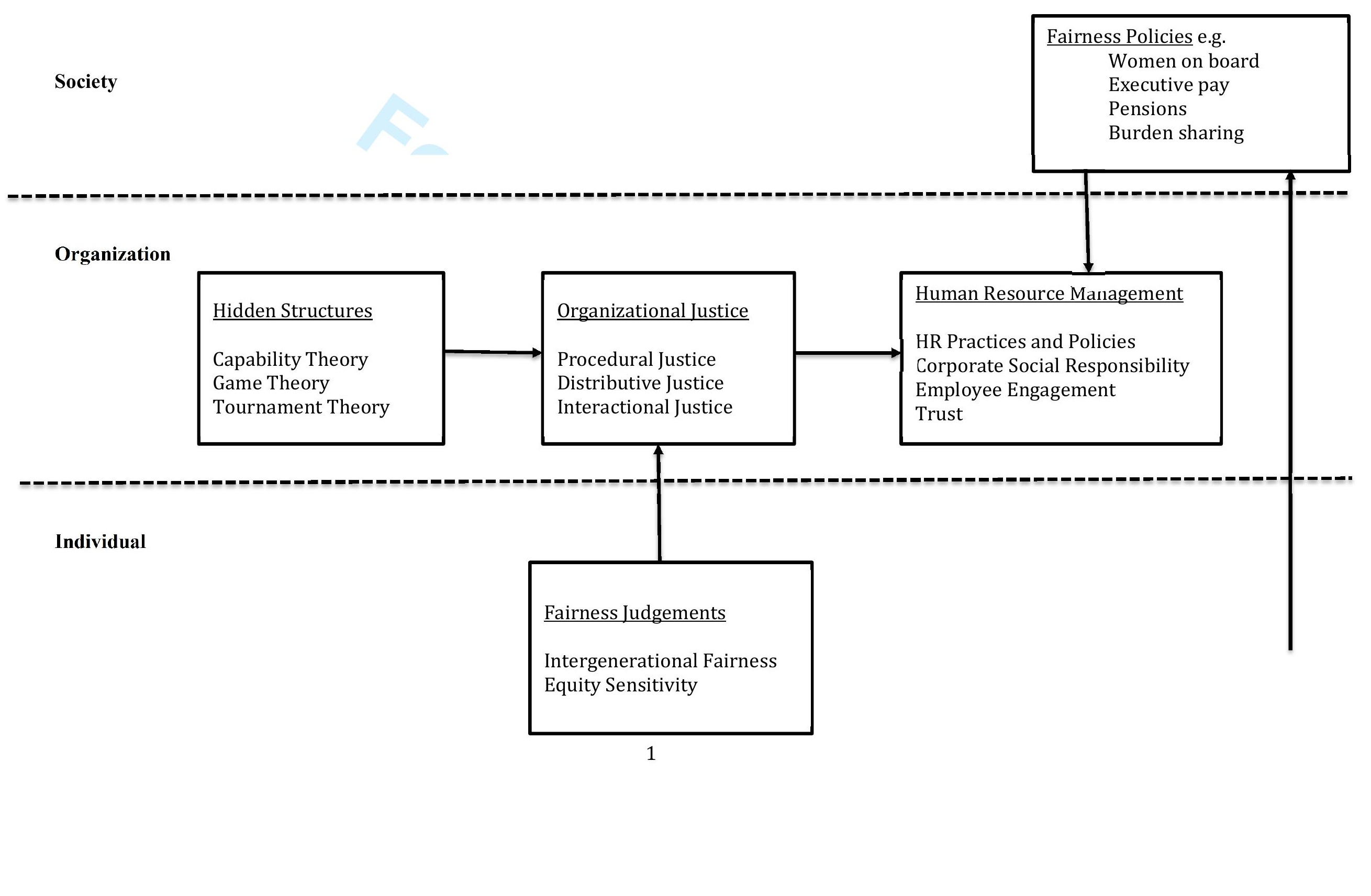

